\title{
The Role of Traditional Knowledge in Indian Management Education
}

\author{
Maziar Jafary \\ PhD Candidate and Research Assistant, School of Sociological and Anthropological Studies, \\ University of Ottawa,mjafa046@uottawa.ca
}

\begin{abstract}
This paper investigates various roles that traditional knowledge can play in Indian managerial education. As it is shown in previous studies, Indian management schools in general and Indian MBA programs in particular lead Indian prospective entrepreneurs toward different sorts of entrepreneurial activities. Although new managerial education in post-cold-war India which mostly endorses entrepreneurship are not bounded to bureaucratic and industrial capitalism, Indian management education is still largely influenced by western and particularly American management schools' structures and syllabuses. According to such scientific management, unlike modern knowledge which is highly entrenched in rational modes of production, traditional knowledge has been confined to pre-capitalist modes of production and distribution of commodities. Still, new movements for reintegration and revival of traditional knowledge in Indian managerial education pretend that India can largely benefit from its traditional treasures for economic boosts. Thus, the conjunction point of modern managerial education and Indian traditional knowledge remains in new types of leadership as well as genuine entrepreneurial skills which are raised and developed by some of Indian managerial scholars. These novel ideas implicate the need for what is called "spiritual leadership" as well as tradition-based projects in Indian entrepreneurship. As such, I will explain in this paper, the ways by which Indian traditional knowledge can intrigue Indian managerial education in numerous ways, both in elite and popular levels.
\end{abstract}

KEYWORDS: Sociology of managerial education, India, Indian traditional knowledge, Indian management studies, Business schools, Management education, MBA education

\section{Introduction}

In social and human sciences, it has mostly been supposed that there exists a contrast between traditional knowledge and modern one in human and social sciences. Still, referring to historical studies, I believe that this distinction is more of socio-historic construction than an objective one. As Sengupta (2019) illustrates, the frontiers between traditional and modern knowledge are more of labels and socio-historical definitions than objective elements. Consequently, he investigates the roots of such distinctions and shows how they might compromise in different situations particularly in entrepreneurship. He believes that developing entrepreneurial ideas based on traditional knowledge might significantly support economic growth in India. Thus, inspired by Sengupta and other researchers' reflections, examining such possible compromises between the modern and the traditional in contemporary Indian management education will be the basis of my discussions in this essay.

Accordingly, I will further define the role of traditional knowledge in modern Indian managerial education. I will firstly discuss the dominant economic paradigm in postcolonial India and then, I will talk about the manners by which various types of Indian management schools may exploit vast opportunities that traditional knowledge opens to them in order to justify their performances and maintain their pertinence in Indian economic development. In this regard, I will distinguish between elitist management institutions and the more popular ones in order to see different paths each type can take to benefit from traditional knowledge. As I will show, although elitist institutions focus mostly on leadership talents, the more popular management institutes may benefit mostly from students' networks and tradition-based skills to support entrepreneurial projects. 


\section{Traditional knowledge in Indian managerial education}

Economists generally differentiate several stages of growth in post-independence Indian economic transitions. However, from a sociological viewpoint I believe that the very paradigm of Indian economic development remained the same since the Nehru era, and that is economic and social expansion of small private sectors by promoting entrepreneurial projects. That said, these projects have largely been considered as attached to modern knowledge and technology. Even though traditional knowledge and traditional modes of production have been crucial in Indian economic mutations, they could not find their deserved place in Indian entrepreneurship. Here it should also be mentioned that the latter finds its roots even in pre-independence era. Suspicion of independence leaders like Gandhi and Nehru about rapid and intense state-led industrialization had huge impacts on leading Indian economic policies towards more support for entrepreneurship and light manufactures. Consequently, during 1950s and 1960s Indian leaders categorically rejected American theorists' propositions for rapid modernization of economy toward a 'high mass consumption' society (as prescribed by Rostow 1990); although, such theories were largely accepted by several developing countries such as Iran - during 1950s and 1960s) and South Korea (during 1960s and 1970s) (Gilman 2003).

What mentioned in the previous paragraph brought later Indian managerial elites to discuss further about exploiting novelty ideas for the sake of entrepreneurship development in the country especially Indian traditional knowledge. In their views, such knowledge can coexist with modern elements in particular situations. As Sengupta (2019) argues, although traditional ways of human living in India have been more or less in harmony with its cultural and social roots (i.e. its traditional ways of being), induction of modern elements has more or less perpetuated conditions of human being in the country. As an example, Sinha et al. (2004) show that "the local traditional construction practice had adapted earthquake-resistant technologies, which are now being lost due to the induction of modern materials and construction techniques in these areas without addressing the seismic safety of modern construction" (Sengupta 2019, 69). Understandably, Sengupta proposes a revival movement towards application of traditional knowledge in modern Indian entrepreneurship on a case by case basis.

Considering what stated above and based on Sengupta's investigations (2019), I can mention five major domains of traditional knowledge which can significantly contribute in modern Indian economic mutations: architecture, housing, irrigation, medicine and folklore heritage (including yoga practices). Besides, Sengupta identifies four Traditional Cultural Expressions (TCE) of each type of traditional knowledge including Materials (e.g. handicrafts), actions (such as performances), verbal expressions (such as poetry) and written expressions. While all of these forms of TCEs are present among the five aforementioned categories of traditional knowledge, each may be dominant in a specific category. For example, verbal expression is more present in medicine than in architecture and written expression is more dominant in mythology and history. That said, the question remains on how Indian entrepreneurs will identify and work on novel opportunities engendered by these five traditional domains on the basis of their expressions? What role might Indian business/management schools play in that regard and how can they train new Indian managerial generations for that sake? In what follows, I will elaborate this issue, but before that, I will briefly talk about the eminence of opportunity recognition skills among management students and important place that traditional knowledge may have in that matter.

As Shepherd and Patzelt (2018) argue, there are five themes related to opportunity recognition in entrepreneurship: prior knowledge, motivation, attention, identity, and emotion. Thus, although education is vital in shaping prior knowledge among future entrepreneurs, the four other themes are mainly formed during a broader process of socialization and integration of entrepreneurs in communities and networks of colleagues and activists. In the same way, Indian management schools in general and MBA programs in particular play a key role in direction of future Indian entrepreneurs towards various sorts of entrepreneurial activities. Consequently, traditional knowledge may be categorically and paradigmatically used in various types of Indian management institutions not only based on apprenticeship but also by benefiting from wider range of human 
experiences such as motivations, identity construction, and emotions. Each of these three elements are vital for opportunity recognition in a diverse context like Indian one: extensive motivations diversify entrepreneurial activities; identity construction further motivates individuals to develop their own projects and networks; and emotions can boost and consolidate human relations during entrepreneurial woks and thus, they may open new opportunities to involved individuals.

As we stated previously and many Indian scholars also pointed out in their recent reflections, new waves of revival for Indian tradition knowledge could play a key role in developing opportunity recognition competences and thus, transforming managerial education in the country so that it would be more in line with its needs. Accordingly, Shepherd and Patzelt's discussions on opportunity recognition (2018) help us to better orient our debates on divergent approaches on the role of traditional knowledge in Indian managerial education.

Before elaborating more details, I should distinguish at least between two general levels of managerial education in India. The first one englobes the elitist level which consists mainly of staterun institutions that attract the best candidates in the country. The other one could be labeled as popular level which contains normally private institutions which are more inclined to lecture based education. Although elitist Indian management schools tend to benefit from the traditional knowledge as a tool to develop entrepreneurship skills, the popular ones seem to be more inclined to use the aforementioned knowledge as a pretext to increase new grounds for entrepreneurial projects such as those in agriculture and arts. Thus, I will further distinguish between these two categories of management institutions regarding their use of traditional knowledge.

\section{Elitist institutions}

As stated above, elitist institutions are mostly the ones that are financed by the central government and attract the best talents from all India. An essential conjunction point of modern managerial education and traditional knowledge in these institutions remains in new types of leadership raised by some of Indian managerial scholars and developed more or less in such schools. These novel ideas implicate the need for what is referred to as "spiritual leadership" in Indian entrepreneurship. As Parthasarathi and his colleagues mention: "spiritual leadership comprises of the values, attitudes and behaviors that are necessary to intrinsically motivate one's self and others so that they have a sense of spiritual survival through calling and citizenship" (Parthasarathi, Rao, \& Reddy 2016, 6). In the same vein, Mahadevan (2012) insists that working climates based on "psychological contracts" should replace classical forms of work based on hierarchical orders. Referring to Bhagavad Gita (2008), he believes that future entrepreneurs should develop the principle of "mutual dependence" as they go through management education. That said, development of such competences among MBA students seem indispensable for opportunity exploitation in entrepreneurial projects based on traditional knowledge. In conjunction with Shepherd and Patzelt's arguments (2018) about opportunity recognition, one can pretend that "spiritual leadership" as it is defined, may largely ameliorate involved persons' motivations, attentions, and positive emotions in the workplace.

Consequently, genuine leadership ideas and tactics can largely be derived from Indian cultural heritage. In this sense, "inspirational leadership", as some Indian scholars talk about, might significantly boost entrepreneurship based on traditional knowledge. Even though many western sociologists believe that traditional way of thought and being are incompatible with modern education, inspirational leadership (particularly feeling the necessity for making difference and progress in the world) could prove the opposite. Along the same line, I believe that Indian epical and mythical world could largely be in compromise with modern and even post-industrial world through encouraging the individuals towards inspiration, hope and respect for the others in situations of difficulty and challenges. In the contemporary sphere of work, full of uncertainties and anxieties, such competences are vital for professional success. 


\section{Popular institutions}

In contrary to elitist institutions, popular Indian institutions (which are normally private ones) may go through different path to integrate traditional heritages into managerial education. In this essay, I will talk about two of the most effective ways by which such institutions may benefit from these heritages.

The first one would be inducing Indian management students to engage further with local communities who work on entrepreneurial and light manufacturing projects. It is supposed that students in popular institutions are more likely to be in touch with local communities and light manufacturing sectors especially because they socialize with other students with similar cultural and geographical background during their studies. Therefore, they could significantly aid these local productions growing their market and networking opportunities in India and beyond. As new Indian managerial generations are more entitled to benefit from information technologies (ITs) and have a broader social network than previous generations, they could fill the gap of marketing issues and technology needs for such local productions. Moreover, these students construct a network among themselves which may definitely be precious if local communities are involved. Aforementioned networks are supposed to be mostly regional ones but they can definitely be broadened by networking strategies.

Besides, I assume that introductory involvement of various aspects of Indian traditional knowledge (especially medicine, folklore heritages and gastronomy) within the course outlines in order to better equip future local entrepreneurs with necessary knowledge and talents to recognize business opportunities in more traditional contexts may be helpful for these potential entrepreneurs. Although, graduated individuals of popular managerial schools may not be necessarily hired by the top manufacturing and distributing organizations, they could certainly assist and even promote entrepreneurial ideas inspired by traditional heritages. As I said at the beginning, traditional knowledge is not forcibly the one that belongs to the past; it could also resolve various modern issues and challenges. The later may not be overcome simply by preemptive prescriptions, and they could be further solved by longstanding packages of traditional heritages.

\section{Conclusion}

While new managerial educations in post-cold-war India are not bounded to bureaucratic and industrial capitalism, Indian management education is still largely influenced by western and particularly American management schools' structures and syllabuses (Thakur \& Babu 2016). According to these structures, the main distinctive feature between modern and traditional knowledge consists of high capacity of modern knowledge for being integrated in material systems of production, and industrial capitalism based on instrumental rationality. In other words, in the opinion of American scientific management, in contrary to modern knowledge which is highly entrenched in rational modes of production, the traditional knowledge has been confined to pre-capitalist modes of production and distribution of commodities. Still, as explained earlier, new educative movements for reintegration and revival of traditional knowledge in Indian managerial education could prove that India can largely benefit from its traditional treasures for economic boosts. That said, it seems that there remains much more time and efforts until the real capacity of Indian traditional knowledge can be discovered and exploited in management institutions. Such efforts need the involvement of scholars and researchers from different disciplines like sociology, psychology, education and even literature. Today's managerial education has proven to need more interdisciplinary approaches rather than classical divisions among educative branches.

\section{References}

Gilman, N. 2003. Mandarins of the future: Modernization theory in Cold War America. Baltimore: Johns Hopkins University Press.

Mahadevan, B. 2012. "Leadership lessons from Bhagavad Gita." Impact, July 2012, pp. 13-16. 
Parthasarathi, S.K., Rao, K.V.S.R., \& Reddy, P.N. 2016. "Spiritual Leadership and its Contribution to Soft Dimensions of Total Quality Management - Relevance to Micro, Small and Medium Enterprises (MSMEs) in India." Indian Journal of Science and Technology, 9(33).

Patton, L. L. 2008. The Bhagavad Gita. London: Penguin Books.

Rostow, W.W. 1990. The stages of economic growth: a non-communist manifesto (3rd ed.). Cambridge, England, New York: Cambridge University Press.

Sengupta, N. 2019. Traditional Knowledge in Modern India: Preservation, Promotion, Ethical Access and Benefit Sharing Mechanisms. New Delhi: Springer.

Shepherd, D. A., \& Patzelt, H. 2018. "Attention and Entrepreneurial Cognition." In: Entrepreneurial Cognition. Palgrave Macmillan, Cham.

Sinha, Ravi, Svetlana Brzev, \& Gayatri Kharel. 2004. "Indigenous Earthquake-Resistant Technologies—An Overview." In 13th World Conference on Earthquake Engineering. Vancouver.

Thakur, M., \& Babu, R. R. 2016. Management Education in India: Perspectives and Practices. New Delhi: Springer. 